\title{
DETECTION OF BISPHENOL A CONTAMINATION IN CANNED CARBONATED BEVERAGES BY GAS CHROMATOGRAPHY
}

\author{
HERMAN SURYADI*, FAATICHATUN NAJA, YAHDIANA HARAHAP \\ Faculty of Pharmacy, Universitas Indonesia, Depok, 16424, Indonesia. Email: hsuryadi@farmasi.ui.ac.id \\ Received: 02 August 2018, Revised and Accepted: 07 August 2018
}

ABSTRACT

Objective: The purpose of this study was to develop sensitive, selective, and valid methods for the detection of bisphenol A (BPA) contamination in beverage samples using gas chromatography (GC)-flame ionization.

Methods: The optimized analysis system employed a long HP-1 capillary column ( $30 \mathrm{~m}$, inner diameter $0.25 \mathrm{~mm}$, film thickness $0.25 \mu \mathrm{m})$, gradient column temperature $\left(150^{\circ} \mathrm{C}-260^{\circ} \mathrm{C}\right.$ at $\left.10^{\circ} \mathrm{C} / \mathrm{min}\right)$, and nitrogen as a carrier gas $(1 \mathrm{~mL} / \mathrm{min})$. Samples were prepared for analysis using ethyl acetate as the extraction solvent.

Results: This method yielded a linearity coefficient of 0.9998, while the limit of detection (LOD) and limit of quantitation (LOQ) were $0.287 \mu \mathrm{g} / \mathrm{mL}$ and $0.956 \mu \mathrm{g} / \mathrm{mL}$, respectively. All validation parameters, including linearity, selectivity, accuracy, precision, LOD, and LOQ meet recognized acceptability criteria. Contamination analysis showed that one of the three beverage brands tested contained $2.4090 \mu \mathrm{g} / \mathrm{mL} \mathrm{BPA}$, and contamination was even higher after heating.

Conclusion: BPA contamination may occur in canned beverages, especially under improper storage conditions. This GC-based BPA detection system may be useful for the detection of BPA contamination in consumer beverages.

Keywords: Bisphenol A, Gas chromatography, Contamination analysis, Validation, Canned beverages.

(C) 2018 The Authors. Published by Innovare Academic Sciences Pvt Ltd. This is an open access article under the CC BY license (http://creativecommons. org/licenses/by/4. 0/) DOI: http://dx.doi.org/10.22159/ijap.2018.v10s1.24

\section{INTRODUCTION}

Bisphenol A (BPA) has been used by polymer industries since 1950 for the production of polycarbonate plastic polymers and epoxy resins. Products containing BPA include infant milk bottles, food and drink containers, thermal papers, compact discs, tape, water pipe, vehicle spare parts, and coatings on metal cans. The widespread use of BPA leads to frequent human exposure through room air, dust, ingestion through food and beverages inside containers, and the water supply [1].

There is a growing concern that this BPA exposure may cause health problems. In fact, BPA has been linked to miscarriage, premature birth, obesity (and associated diseases), immune dysfunction, and disruption of neural and hormonal signaling. Several studies have reported that BPA compounds can be released from containers containing polycarbonate or epoxy resins under certain conditions, thereby contaminating food and beverages [2]. The European Food Safety Authority (EFSA) has set $5 \mu \mathrm{g} / \mathrm{kg}$ as the maximum tolerable limit of consumed BPA (EFSA, 2014), a substantial decrease from the previous limit of $50 \mu \mathrm{g} / \mathrm{kg} \mathrm{BW}$ [3], in response to studies demonstrating the risks from consuming BPA.

BPA can be released from polymers through exposure to heat, acidic solutions, and alkaline solutions. Therefore, factory sterilization may cause the release of BPA into canned beverages. In addition, leaving unconsumed beverage in an opened can without refrigeration and exposed to sunlight may also cause contamination.

Due to the potential dangers of trace BPA contamination, a sensitive analytical method is required for product testing [4]. Such analytical methods have been developed based on high-performance liquid chromatography (HPLC) with UV detection [5,6], electron catching detection [7,8], mass spectrometry (MS) [9], FID/MS gas chromatography (GC) [10-13], and enzyme-linked immunosorbent assay [14]. However, GC is more selective and sensitive than HPLC and can detect contaminants with shorter analysis times and greater single compound resolution. GC using a longer column yields even higher separation efficiency (Wang and Burleson, 1999) [15,16]. Therefore, we developed a GC-based method using a long column for the detection of BPA and employed this method to demonstrate the presence of BPA in test samples of canned beverages.

\section{MATERIALS AND METHODS}

\section{Materials}

In this study, 18 canned beverage samples of three different brands were tested (coded A, B, and C for samples with 6 months until the expiry date and D, E, and F for samples with 2 years until the expiry date). Samples were obtained from Depok City, West Java. Standards and suppliers were as follows: BPA (Sigma-Aldrich), acetate ethyl (Merck), methanol pro-HPLC (Merck), and distilled water (Aqua Bidest pro HPLC).

Optimal analysis conditions were identified as follows. First, the optimal detector temperature was chosen by injecting $3 \mu \mathrm{L}$ standard BPA solution at $100 \mathrm{ppm}$ into the GC system with gas water flow at $1 \mathrm{~mL} / \mathrm{min}$ and one of the three column temperature conditions, $250^{\circ} \mathrm{C}[5,17], 280^{\circ} \mathrm{C}[6,18]$, or controlled gradient increasing from $150^{\circ} \mathrm{C}$ to $260^{\circ} \mathrm{C}$ at $10^{\circ} \mathrm{C} / \mathrm{min}[7,19]$. Next, the optimal analysis volume was chosen by injecting 1 , 2, or $3 \mu \mathrm{l}$ BPA standard at $15 \mathrm{ppm}$ into the GC system using $1 \mathrm{~mL} / \mathrm{min}$ gas water flow and optimized temperature conditions. The optimal gas water flow was chosen by injecting $3 \mu \mathrm{l}$ of standard $35 \mathrm{ppm}$ BPA solution into the GC system with gas water flow at $0.8,1$, or $1.2 \mathrm{~mL} / \mathrm{min}$. The optimal analysis condition for each parameter was scored based on the separation between the two nearest peaks (or resolution, R), peak sharpness, follow-up factor, peak release resistance time, and column efficiency (theoretical plate number $[\mathrm{N}]$ and height equivalent to the theoretical plate [HETP]). 
Next, system conformity tests were conducted. A standard 15 ppm BPA solution was prepared and $3.0 \mu \mathrm{L}$ was injected into the GC system under optimized conditions (above). Results were graded by the repetition score $(\% \mathrm{CV})$ for resolution $(\mathrm{R})$, peak sharpness, follow-up factor, peak release resistance time, and column efficiency ( $\mathrm{N}$ and HETP).

The BPA analysis method was validated by linearity testing and construction of calibration curves. Briefly, $100 \mu \mathrm{g} / \mathrm{mL}$ standard BPA solution was diluted in methanol to $2,4,6,8,10$, and $15 \mu \mathrm{g} / \mathrm{mL}$ (ppm), and $3.0 \mu \mathrm{L}$ of each solution injected into the GC system. The peak (y) versus analytic concentration $(\mathrm{x})$ was then subjected to regression analysis to obtain a correlation coefficient (r). From the obtained calibration curve, the limit of detection (LOD) and limit of quantification (LOQ) were derived.

For selectivity analysis, a blank solution (solvent), BPA standard at $15 \mathrm{ppm}$, and spiked BPA solutions extracted as for beverage samples (below) were injected at $3 \mu \mathrm{L}$ and retention times were compared. The spiked solution was prepared using the standard addition method to sample $50 \%, 100 \%$, and $150 \%$ BPA concentrations. Each solution was injected into the GC system at $3 \mu \mathrm{L}$ under optimized conditions. Tests were conducted in triplicate for selectivity analysis and 6 times for the evaluation of precision. Acquisition tests were conducted to assess accuracy, and \% KV was calculated to assess precision.

Finally, BPA levels in the beverage samples were examined. $3 \mu \mathrm{L}$ of each extraction solution was injected into the GC system under optimized conditions, and the acquired peak was analyzed. Canned beverages were first sonicated for $30 \mathrm{~min}$ to remove carbon dioxide. Samples $(30 \mathrm{~mL}$ per container) were extracted by mixing with $30 \mathrm{~mL} 90 \%$ acetate ethyl, shaking gently for $30 \mathrm{~s}$, and then leaving the mixture to sit until clear separation of the organic layer and water layer. Acetate ethyl was used because its close polarity to BPA suggests the suitability for extraction. After layer separation, the 30-mL organic layer was transferred to a reaction tube and the water layer transferred to a glass breaker for second and third extractions. The extraction process was repeated each with $30 \mathrm{~mL} 99 \%$ acetate ethyl [2]. All the three extracts were combined and evaporated at $60^{\circ} \mathrm{C}$ using a water bath. The residue was dissolved in $5 \mathrm{~mL}$ methanol and filtered using Whatman filter paper with $0.45 \mu \mathrm{m}$ pore size. Samples of extract ( $3 \mu \mathrm{l}$ ) were then injected into the GC system under optimized analysis conditions. Each sample was tested in triplicate.

\section{RESULTS AND DISCUSSION}

\section{Determination of optimal analysis conditions}

Optimal detector temperature selection

Comparison of chromatographic results using different temperatures (two isothermal conditions and a gradient of $10^{\circ} \mathrm{C} / \mathrm{min}$ from $150^{\circ} \mathrm{C}$ to $260^{\circ} \mathrm{C}$ ) defined the optimal temperature for separation in methanol as $243-250^{\circ} \mathrm{C}$, at which the retention time was $9.713 \mathrm{~min}$ (Table 1 ).

\section{Injection volume selection}

An optimal injection volume of $3 \mu \mathrm{l}$ was chosen based on highest peak area, follow-up factor, and resolution among 1,2 , and $3 \mu$ l samples of 15 ppm BPA (Table 2).

\section{Flow rate selection}

A flow rate of $1 \mathrm{~mL} / \mathrm{min}$ was chosen among $0.8,1.0$, and $1.2 \mathrm{~mL} / \mathrm{min}$ based on highest theoretical plate number, HETP, and resolution as well as shortest retention time (Table 3).

\section{System comparability test}

The $\% \mathrm{KV}$ for the CG system under optimized conditions was $1.377 \%$ as calculated from six repeated injections of a standard $15 \mathrm{ppm}$ BPA solution (Table 4), which meets the International Council for Harmonization criteria (ICH, 1996).

\section{Analysis method validation using KCKT}

Calibration curve construction and linearity testing

A calibration curve was constructed under these optimized conditions using standard BPA concentrations of $2,4,6,8,10$, and $15 \mathrm{ppm}$ (Table 5). The calibration curve equation obtained was $\mathrm{y}=41.485 \mathrm{x}$ - 75.602, and the correlation coefficient $(r=0.9998)$ meets the ICH linearity standards (ICH, 1996).

\section{LOD LOQ determination}

The LOD and LOQ were derived from the calibration curve regression equation as $0.2870 \mu \mathrm{g} / \mathrm{mL}$ and $0.9563 \mu \mathrm{g} / \mathrm{mL}$, respectively.

\section{Selectivity test}

In selectivity testing, BPA solutions subjected to the same extraction process as beverage samples showed no difference in retention time compared to BPA standards under optimized conditions (9.714 min), while a matrix solution produced no BPA signal, indicating selectivity for BPA as shown in Fig. 1.

\section{Accuracy and precision}

Accuracy and precision were assessed from the results of three replicates each at 2 and $4 \mathrm{ppm}$ and 6 replicates at $6 \mathrm{ppm}$. Data obtained met the smart criteria, with accuracy within $80-110 \%$ and $\% \mathrm{KV}$ precision no more than $5 \%$ (Table 6 ) $[8,20]$.

\section{Beverage sample BPA analysis}

Samples A, B, and C had expiry dates in 6 months, and samples D, E, and F had expiry dates in 2 years. Samples A, B, and C were stored in a fridge, at room temperature, or in an oven for 30,60 , or 120 min before the extraction. Results are presented in Table 7. One brand (A) exhibited BPA contamination even when refrigerated and contamination increased with heating, while another brand (C) exhibited contamination only after heating.

\section{DISCUSSION}

We have established a GC-based method for the detection of BPA in canned beverages with high linearity, sensitivity, specificity, and accuracy. This method was able to detect relatively small amounts of BPA in extracted beverage samples. In fact, one sample with an expiry date in 6 months exhibited BPA contamination even when stored under refrigeration. Further, contamination increased when the samples were heated. In general, BPA levels were higher in cans closer to the expiry date (6 months vs. 2 years). These results suggest that BPA contamination of canned beverages is possible and is exacerbated by improper storage, underscoring the importance of this optimized GCbased detection method.

This BPA contamination may be caused by layering differences (type, amount, etc.) or the sterilization process (high temperature) used by many canned beverage manufacturers. Unintentional heat exposure during storage and transportation may also contribute. Xu-Liang et al. measured BPA concentrations of 0.18-0.45 $\mu \mathrm{g} / \mathrm{l}$ in 72 canned beverage

Table 1: Optimal temperature results using a 100 ppm BPA standard

\begin{tabular}{llllll}
\hline Temperature method & Retention time (min) & Theoretical plates (N) & HETP & Follow-up factor (Tf) & Resolution (R) \\
\hline Isotherm $250^{\circ} \mathrm{C}$ & - & - & - & - & - \\
Isotherm $280^{\circ} \mathrm{C}$ & - & - & - & - & - \\
Gradient method* & 9.713 & 430768.914 & 0.0696 & 1.026 & 185.552 \\
\hline
\end{tabular}

${ }^{*} 150^{\circ} \mathrm{C}$ to $260^{\circ} \mathrm{C}$ at $10^{\circ} \mathrm{C} / \mathrm{min}$ 
Table 2: Optimal temperature results using a 100 ppm BPA standard

\begin{tabular}{lllllll}
\hline Injection volume & Area $(\boldsymbol{\mu V} / \mathbf{s})$ & Retention time (min) & Theoretical plates (N) & HETP & Follow-up factor (Tf) & Resolution (R) \\
\hline $1 \mu \mathrm{L}$ & 205 & 9.698 & 158755.709 & 0.1889 & 1.248 \\
$2 \mu \mathrm{L}$ & 300 & 9.704 & 136567.681 & 0.2197 & 1.093 \\
$3 \mu \mathrm{L}$ & 572 & 9.714 & 366156.439 & 0.0819 & 1.367 & 84.114 \\
\hline
\end{tabular}

Table 3: Optimal flow rate using a 15 ppm BPA standard

\begin{tabular}{|c|c|c|c|c|c|c|}
\hline Flow rate $(\mathrm{mL} / \mathrm{min})$ & Area $(\mu V / s)$ & Retention time (min) & Theoretical plates $(\mathrm{N})$ & HETP & Follow-up factor (Tf) & Resolution (R) \\
\hline 0.8 & 226 & 10.553 & 530604.240 & 0.0565 & 1.073 & 134.953 \\
\hline 1 & 508 & 9.740 & 368468.159 & 0.0814 & 1.126 & 71.932 \\
\hline 1.2 & 594 & 7766.668 & 7766.668 & 3.8626 & 0.000 & 31.080 \\
\hline
\end{tabular}

Table 4: System comparability test for 15 ppm BPA

\begin{tabular}{|c|c|c|c|c|c|c|c|}
\hline Peak wide $(\mu V / s)$ & $\begin{array}{l}\text { Retention time } \\
\text { (min) }\end{array}$ & $\begin{array}{l}\text { Standard } \\
\text { deviation (SD) }\end{array}$ & $\begin{array}{l}\text { Variation } \\
\text { coefficient }(\% \mathrm{KV})\end{array}$ & $\begin{array}{l}\text { Theoretical } \\
\text { plates }(\mathrm{N})\end{array}$ & HETP & $\begin{array}{l}\text { Follow-up factor } \\
\text { (Tf) }\end{array}$ & Resolution (R) \\
\hline 572 & 9.714 & 7.78878 & 1.3771 .377 & 366156.44 & 0.0818 & 1.367 & 90.016 \\
\hline 572.3 & 9.721 & 7.78878 & & 344506.59 & 0.0870 & 1.183 & 143.478 \\
\hline 564 & 9.721 & & & 346577.92 & 0.0866 & 1.149 & 143.725 \\
\hline 567 & 9.711 & & & 369028.05 & 0.0813 & 1.234 & 169.177 \\
\hline 568 & 9.709 & & & 366425.84 & 0.0818 & 1.057 & 168.785 \\
\hline 551 & 9.706 & & 1.377 & 418449.312 & 0.0717 & 1.148 & 169.690 \\
\hline
\end{tabular}

Table 5: Calibration curve, LOD, and LOQ BPA data in chosen condition

\begin{tabular}{llllll}
\hline Concentration $(\mathbf{p p m})$ & Peak wide $(\mathbf{y})$ & $\mathbf{Y i}$ & $(\mathbf{y}$-yi) & $\mathbf{S}(\mathbf{y} / \mathbf{x})$ & $\mathbf{L O D}(\boldsymbol{\mu g} / \mathbf{m L})$ \\
\hline 2 & 11 & 7.368 & 13.191 & 3.9675 & 0.287 \\
4 & 91.1 & 90.338 & 0.581 & & \\
6 & 170.5 & 173.308 & 7.885 & & \\
8 & 255.4 & 256.278 & 0.771 & & \\
10 & 334.4 & 339.248 & 25.503 & & \\
15 & 550.8 & 546.673 & 17.032 & & \\
\hline
\end{tabular}

LOD: Limit of detection, LOQ: Limit of quantitation

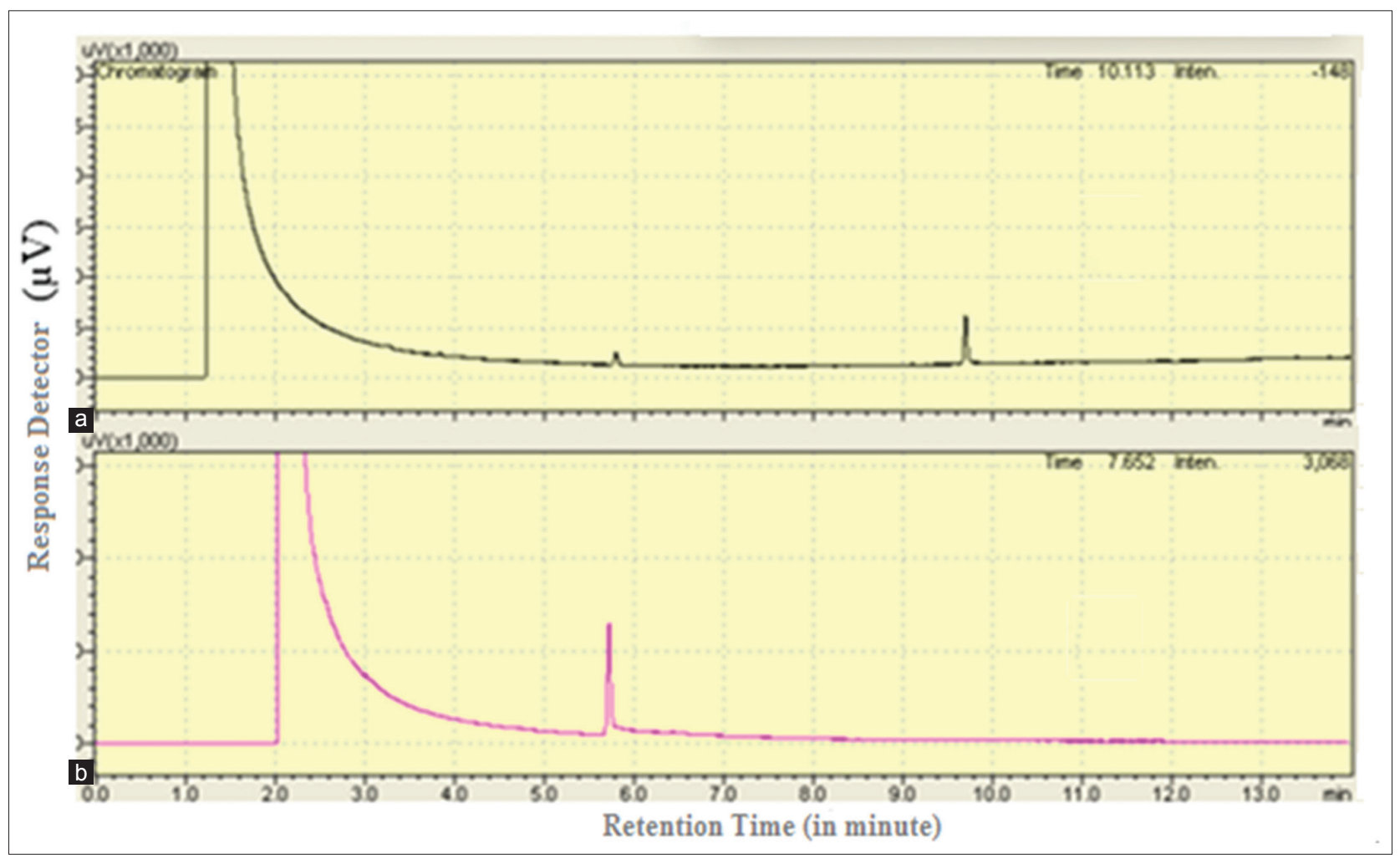

Fig. 1: Chromatogram of selectivity test for sample solution (a) and $100 \mathrm{ng} / \mathrm{mL}$ standard BPA solution (b). Conditions were $3 \mu \mathrm{l}$ injection volume and gradient temperature $\left(10^{\circ} \mathrm{C}\right.$ increase $/ \mathrm{min}$ from 150 to $\left.260^{\circ} \mathrm{C}\right)$ 
Table 6: Accuracy and precision at 6 ppm BPA

\begin{tabular}{|c|c|c|c|c|c|c|c|}
\hline Initial rate $(\mu \mathrm{g} / \mathrm{mL})$ & Peak wide total & Sample wide total & Counted rate $(\mu \mathrm{g} / \mathrm{mL})$ & Mean concentration $(\mu \mathrm{g} / \mathrm{mL})$ & SD & KV(\%) & $\%$ UPK \\
\hline \multirow[t]{6}{*}{6} & 208.4 & 35.5 & 5.9902 & 5.8588 & 0.1124 & 1.87 & 99.84 \\
\hline & 214.1 & & 6.1276 & & & & 99.87 \\
\hline & 199.1 & & 5.7660 & & & & 96.10 \\
\hline & 199.2 & & 5.7684 & & & & 99.27 \\
\hline & 207 & & 5.9564 & & & & 95.66 \\
\hline & 194 & & 5.6431 & & & & 96.14 \\
\hline
\end{tabular}

Table 7: Beverage sample results

\begin{tabular}{ll}
\hline Sample & Concentration (ppm) \\
\hline A & \\
Fridge $\left(2-8^{\circ} \mathrm{C}\right)$ & 2.4090 \\
Room $\left(25-30^{\circ} \mathrm{C}\right)$ & 2.6773 \\
Oven $\left(40^{\circ} \mathrm{C}\right) 30 \mathrm{~min}$ & 4.0304 \\
Oven $\left(40^{\circ} \mathrm{C}\right) 60 \mathrm{~min}$ & 4.5037 \\
Oven $\left(40^{\circ} \mathrm{C}\right) 120 \mathrm{~min}$ & 6.3830 \\
Long $(\mathrm{D})\left(25-30^{\circ} \mathrm{C}\right)$ & 3.5170 \\
$\mathrm{~B}$ & \\
Fridge $\left(2-8^{\circ} \mathrm{C}\right)$ & - \\
Room $\left(25-30^{\circ} \mathrm{C}\right)$ & - \\
Oven $\left(40^{\circ} \mathrm{C}\right) 30 \mathrm{~min}$ & - \\
Oven $\left(40^{\circ} \mathrm{C}\right) 60 \mathrm{~min}$ & - \\
Oven $\left(40^{\circ} \mathrm{C}\right) 120 \mathrm{~min}$ & - \\
Long $(\mathrm{D})\left(25-30^{\circ} \mathrm{C}\right)$ & - \\
$\mathrm{C}$ & \\
Fridge $\left(2-8^{\circ} \mathrm{C}\right)$ & - \\
Room $\left(25-30^{\circ} \mathrm{C}\right)$ & - \\
Oven $\left(40^{\circ} \mathrm{C}\right) 30 \mathrm{~min}$ & 2.4957 \\
Oven $\left(40^{\circ} \mathrm{C}\right) 60 \mathrm{~min}$ & 2.7625 \\
Oven $\left(40^{\circ} \mathrm{C}\right) 120 \mathrm{~min}$ & 3.3201 \\
Long $(\mathrm{D})\left(25-30^{\circ} \mathrm{C}\right)$ & 2.2402 \\
\hline
\end{tabular}

samples from local supermarkets in Canada using a GC-MS method with a LOD of $0.0074 \mu \mathrm{g} / \mathrm{L}[9,21]$. Therefore, the BPA concentrations found in the current study are relatively high.

In this study, samples B and C still meet the safety standards of the BPOM and the US Environmental Protection Agency limit of $0.6 \mathrm{ppm}$. However, sample A is not safe for consumption as the BPA concentration was above $0.6 \mathrm{ppm}$. If an adult weighing $60 \mathrm{~kg}$ consumed one sample A canned beverage $(330 \mathrm{~mL})$ each day, BPA exposure would equal $13.25 \mu \mathrm{g} / \mathrm{kg}$ body weight/day, which greatly exceeds the tolerable limit of $5 \mu \mathrm{g} / \mathrm{kg}$ BW established by the EFSA. Exposure will be even higher if the beverage is not consumed immediately or is stored improperly, such as at high temperature. Thus, storage conditions during transportation and before sale may be critical for the reduction of BPA contamination risk.

\section{CONCLUSION}

We have developed and validated an optimized GC-based method for the detection of BPA contamination in canned beverages. The method uses a long HP- 1 capillary column (column length $30 \mathrm{~m}$, inside diameter $0.25 \mathrm{~mm}$, and film thickness $0.25 \mu \mathrm{m}$ ), flame ionization detection, a gradient column temperature $\left(150^{\circ} \mathrm{C}\right.$ to $260^{\circ} \mathrm{C}$ at $\left.10^{\circ} \mathrm{C} / \mathrm{min}\right)$, and nitrogen as the gas carrier at a flow rate of $1 \mathrm{~mL} / \mathrm{min}$. Total analysis time was $14 \mathrm{~min}$. The method meets the international standards for linearity ( $\mathrm{r}=0.998$ linearity) with LOD of $0.287 \mu \mathrm{g} / \mathrm{mL}$ and LOQ of $0.947 \mu \mathrm{g} / \mathrm{mL}$. Storage temperature and storage time facilitate BPA migration into canned beverages. BPA concentrations appear higher in canned beverages that have been on the market for a longer time (closer to the expiry data) than newly distributed products.

\section{REFERENCES}

1. Ng HW, Shu M, Luo H, Ye H, Ge W, Perkins R, et al. Estrogenic activity data extraction and in silico prediction show the endocrine disruption potential of bisphenol A replacement compounds. Chem Res Toxicol 2015;28:1784-95.
2. Shrinithivihahshini N, Mahamuni D, Praveen N. Bisphenol a migration study in baby feeding bottles of selected brands available in the Indian market. Curr Sci 2014;106:1081-84.

3. European Food Safety Authority (EFSA). Opinion of the scientific panel on food additives, flavourings, processing aids and materials in contact with food (AFC) on request from the commission related to 2,2 bis(hydroxyphenol)propane (bisphenol A). Eur Food Soc Authority 2006;428:1-75.

4. Errico S, Bianco M, Mita L, Migliaccio M, Rossi S, Nicolucci C, et al. Migration of bisphenol A into canned tomatoes produced in Italy: Dependence on temperature and storage conditions. Food Chem 2014; 160:157-64.

5. Nagel R., Bosch-Domenech A, Satorra A, Garcia-Montalvo J. One, Two, (Three),Infinity:NewspaperandLabBeauty-ContestExperiments.Barcelone: Universitat Pompeu Fabra. Available from: http://www.citeseerx.ist.psu. edu/viewdoc/download?doi=10.1.1.479.4035\&rep=rep1\&type=pdf.

6. Careri M, Furlattini L, Mangia A, Musc M, Anklam E, Theobald A, et al. Supercritical fluid extraction for liquid chromatographic determination of carotenoids in spirulina Pacifica algae: A chemometric approach. J Chromatogr A 2001;912:61-71.

7. Inoue K, Mizuno T, Wada K, Hagiwara M. Novel RING finger proteins, air $1 \mathrm{p}$ and air $2 \mathrm{p}$, interact with $\mathrm{hmt} 1 \mathrm{p}$ and inhibit the arginine methylation of npl3p. J Biol Chem 2000;275:32793-9.

8. Sajiki H, Hirota K. Formation of $\mathrm{Pd} / \mathrm{C}$-ethylenediamine complexes $[\mathrm{Pd} / \mathrm{C}(\mathrm{en})]$ and its application to selective hydrogenations. scientific magazine of synthesis 2001;59:109-20.

9. Pedersen B, Rasmussen KE. Liquid-liquid-liquid microextraction for sample preparation of biological fluids prior to capillary electrophoresis. Anal Chem 1999;71:2650-6.

10. Jeannot R, Sabik H, Sauvard E, Dagnac T, Dohrendorf K. Determination of endocrine-disrupting compounds in environmental samples using gas and liquid chromatography with mass spectrometry. J Chromatogr A 2002;974:143-59.

11. Zafra G, Del Olmo M, Pulgar R, Navalon A, Vilchez JL. Determination of bisphenol-A and related compounds in human saliva by gas chromatography-mass spectrometry. Chromatographia 2002;56:213-8.

12. Harmita H, Mansur U, Stephanie S. Determination of docosahexaenoic acid in infant formulas with gas chromatography. Asian J Pharm Clin Res 2018;11:247-50.

13. Sujatha P, Evanjaline M, Muthukumarasamy S, Mohan VR. Determination of bioactive components of Barleria courtallica Nees (Acanthaceae) by gas chromatography-mass spectrometry analysis. Asian J Pharm Clin Res 2017;10:273-83.

14. De Meulenaer B, Baert K, Lanckriet H, Van Hoed V, Huyghebaert A. Development of an enzyme-linked immunosorbent assay for bisphenol A using chicken immunoglobulins. J Agric Food Chem 2002;50:5273-82.

15. Wang FC, Burleson D. The development of pyrolysis-fast gas chromatography for analysis of synthetic plymers. J Chromatogr A 1999;833:111-9.

16. Chaskar PK, Tank SH, Doshi GM. Gas chromatography-mass spectroscopy studies on Cestrum nocturnum macerated methanolic extract. Asian J Pharm Clin Res 2017;10:259-63.

17. Rykowska I, Szymanski A, Waisak W. Determination of bisphenol A in drinking water using new SPE sorbents with chemically bonded ketamine group. Pol J Food Nutr Sci 2005;13:355-61.

18. Miryani A, Leilani G, Zenilda D. Hollow fiber liquid-phase microextration-gas chromatography-mass spectrometry method to analyze bisphenol A and other plasticizer metabolites. J Chromatogr A 2017;1481:31-6.

19. Szyrwinska K, Lulek J. Chemically bonded phases for the analysis of trace amounts of organic pollutants. Toxicol Mech Methods 2008;18:537-42.

20. International Conference on Harmonisation (ICH). Guidance for Industry: Validation of Analytical Procedures; 1996.

21. Cao XL, Corriveau J, Popovic S. Levels of bisphenol A in canned soft drink products in Canadian markets. JAgric Food Chem 2009;57:1307-11. 